\title{
Attention as Proof of Faith
}

\section{DÁVID MARNO}

Abstract: This essay asks the question: can a poem serve as prooffor religious belief? By reading John Donne's devotional sonnets in light of the Pauline letters, the argument unfolds in two parallel directions. First, it shows that in Paul's first letter to the Corinthians, the concept of pistis (proof or belief) refers primarily to Christian faith as a self-referential proof. Second, it argues that Donne's poems enact this sense of faith-as-proof by using language as material for attention exercises. The essay concludes by suggesting that the connection that these poems reveal about certainty and attentiveness gives us a way to think about the continuity between early modern devotion and emergent discourses of philosophy.

One of John Donne's Holy Sonnets ends with the following couplet: "One short sleepe past, we live eternally / And Death shalbe no more, Death thou shallt dy" (16). ${ }^{1}$ I would like to begin by asking a deliberately naïve question about these two lines: what makes the speaker of the poem, whoever he may be, so certain that what he is saying is true? The last line first proclaims some kind of final victory over death, and then turns directly to death and says to its face: "thou shallt dy." On what grounds would, or indeed could, anyone say such a thing? In other words, what is the proof, the evidence behind this proclamation?

A predictable answer would point out that my question is mistaken: poetry does not need proofs at all, because it does not contain propositional statements. The realm of poetry is a hypothetical, invented world; or as Philip Sidney says in the Defense of Poetry, the poet "nothing affirms, and therefore never lieth," because

1 All quotations are from Gary A. Stringer, ed., The Variorum Edition of the Poetry of John Donne, volume 7, part I, The Holy Sonnets (Bloomington: Indiana University Press, 2005). On occasion I have slightly modernised the spelling. 
he invents his own world, instead of making statements about what already exists, instead of saying what is already given. On this view the last two lines of "Death be not proud" should be based on nothing but the poem itself; the poem, so to speak, is the only proof of itself, of its final statement.

But, of course, another and equally predictable answer is that on the contrary, Donne's poem does rely on an external proof: the statement that "Death shalbe no more" on this view is an expression of the Christian doctrine of the resurrection of the dead, which the poem paraphrases in the penultimate line's "[o]ne short sleep past, we live eternally." The proof that it relies on, then, is the faith of the Christian, their trust in this particular doctrine.

Are these two readings of the poem compatible? It is not immediately obvious how they could be: for a purely poetic reading, the "proof" of the poem's final statement must be the poem itself; but from a Christian perspective, on the contrary, the proof is something external to the poem, it is a Christian doctrine, or rather the faith in it. In fact, when we talk about Donne, who was convinced that the doctrine of the resurrection of the dead somehow contained every other Christian doctrine, one might say that the proof of the couplet is Christianity itself. ${ }^{2}$

So far, I have used the term "invention" in the specific poetic sense to refer to the invention of fiction that Aristotle finds central to poetry. But invention in the Renaissance is a more fluid and primarily rhetorical category that ranges from discovery and finding to creation and fiction. It is the first part of classical Aristotelian rhetoric, defined as the process of coming upon the proofs that we need to convince an audience. It might seem that rhetoric could mediate between poetic labour and religious doctrine: on this view, the poem's work would consist in inventing the proofs that would generate faith in a given audience.

But if we turn to Donne's source for the poem, chapter 15 in Saint Paul's first letter to the Corinthians, we find that this rhetorical approach may not be sufficient to resolve the conflict between poetic and Christian evidence. Here is the passage in Paul's letter: “. . . then shall be brought to pass the saying that is written, Death is swallowed up in victory. O death, where is thy sting? $\mathrm{O}$ grave, where is thy victory?"3

The end of "Death be not proud" is a close paraphrase of Paul's own proclamation; Donne even follows Paul's move from declaring death's end in third person,

2 "[A]ll the Gospell, all our preaching, is contracted to that one text, To beare witnesse of the Resurrection" (Potter and Simpson 4:355).

3 All references to the Bible are to the 1611 King James version. 


\section{DÁVID MARNO}

and then turning to a mockery of death in the first person, directly addressing death. The difference is that Paul's proclamation comes toward the end of an argument, an argument concerned with the resurrection of the dead, and an argument that takes up the whole chapter of Corinthians 15. In other words, in Paul's letter the mockery is framed as a conclusion, raising the obvious question: what evidence does Paul offer for this conclusion, for his final expression of the belief in the resurrection of the dead?

The first and most obvious answer to this question seems to be that Paul's proof is the resurrection of Christ, the subject of much of Corinthians 15. But this is not entirely true: the problem Paul faces in this chapter is that even though the Corinthians already believe that Christ was resurrected, they still doubt the general resurrection. ${ }^{4}$ In other words, they accept Christ's resurrection as the object of their faith; what they do not accept is that Christ's resurrection is a proof of the general resurrection. Therefore, what Paul needs to prove is not a fact, i.e. the fact of Christ's resurrection, but a fact as proof, the notion that Christ's resurrection was not simply a random, individual case, but a sign, a proof of God's will to fulfil the ancient promise of defeating death.

It is in this context that Paul offers an argument that might at first sight appear spectacularly circular: "For if the dead rise not, then is not Christ raised. And if Christ be not raised, your faith [pistis] is vain ... . But now is Christ risen from the dead, and become the first fruits of them that slept." The argument here is not A (Christ is risen), therefore B (general resurrection is going to happen). Instead it is: if you do not believe the resurrection of the dead, then you do not really believe Christ's resurrection either, then your faith in Christ's resurrection is in vain - it is uncertain, purposeless, empty, hasty. Ergo: You have to believe that Christ is resurrected and that this means he is a first fruits, a proof of the resurrection of the dead.

This explains a curious fact that, to my knowledge, New Testament scholarship has never really accounted for, namely that Paul never uses the word "pistis" in the sense as proof but only in the sense of faith (with one, rather fascinating, exception). ${ }^{5}$ In this passage, the two rhetorical senses of pistis, proof and faith, are collapsed into

4 "Now if Christ be preached that he rose from the dead, how say some among you that there is no resurrection of the dead?"

5 The term "pistis" refers to faith throughout the Pauline corpus. The only occurrence of pistis in the sense of proof or assurance that is attributed to Paul is in Acts 17:31: "Because he hath appointed a day, in the which he will judge the world in righteousness by that man whom he hath ordained; whereof he hath given assurance unto all men, in that he hath raised him from the dead." 


\section{ATTENTION AS PROOF OF FAITH}

each other: the proof of the resurrection of the dead is not Christ's resurrection as a fact but Christ's resurrection as belief; i.e. the only proof for the final victory over death is faith in the euangelion that suggests that Christ's resurrection is proof of God's will to resurrect the dead. ${ }^{6}$ In 1 Corinthians 15, the devotion of faith replaces the rhetoric of proofs: the question of inventio in Paul's argument is not one of finding available proofs but of inventing one's own faith as proof.

While in Corinthians Paul thus collapses the two rhetorical senses of pistis, faith and proof, into one, a unity I paraphrased as "faith as proof," at the same time he also distinguishes between two senses of faith. On the one hand, there is "faith in vain," that is, believing without just reason, authority, proof, certainty. Such faith consists in simply accepting an article of faith without recognising how it is related to other aspects of the euangelion as a totality. Paul contrasts this "faith in vain" with the faith that is certain, faith that, so to speak, proves itself. That the advocating of this latter faith-as-proof is the goal of 1 Corinthians 15 is clear from the very beginning of the letter: "I declare unto you the gospel which I preached unto you, which also you have received, and wherein yee stand. By which also yee are saved, if yee keep in memory what I preached unto you, unless yee have believed in vain." Faith is vain, unproved, uncertain, unless its subject is "kept in memory," and unless the believer continuously "stands in" the matter of his faith. What I called faithas-proof, then, is this real or certain faith sustained by the believer's active labour of holding onto it, of standing in it.

\section{II}

In the Meditations, the sixteenth-century Dominican theologian and devotional author Luis de Granada distinguishes between faith and the thinking, attentive consideration of "the mysteries of our faith":

the principal matter of this Booke, is of Meditation and Consideration of things appertaining to Almighty God, and of the principal mysteries of the Catholike faith. The very thing that moved me to treate of this matter, was for that I understood, that one of the principall causes of all the evils that be in this world, is the lack of

Interestingly, the context of this passage is Paul's explanation of the euangelion to the Greek Epicureans and Stoics in Athens - in other words he appeals to their understanding of pistis.

6 In a sense this is precisely what Hebrews 1:11 argues: "Now faith is the substance of things hoped for, the evidence of things not seen." 


\title{
DÁVID MARNO
}

Consideration; according as the Prophet Jeremy signified, when he said: All the earth is destroyed with desolation, because there is none that thinketh with attention upon the things appertaining unto God. Whereby it appeareth, that the very cause of our evils, is not so much the want of faith, as the want of due consideration of the mysteries of our faith. (2-3)

Donne in one of his sermons makes a similar distinction when he distinguishes "imaginary" or "implicit" faith from the real faith that is supported by cognitive certainty:

\begin{abstract}
As therefore it is not enough for us, in our profession to tell you, Qui non crediderit, damnabitur, Except you beleeve all this, you shall be damned, without we execute that Commission before, Ite praedicate, go and preach, work upon their affections, satisfie their reason; so it is not enough for you, to rest in an imaginary faith, and easinesse in beleeving, except you know also what, and why, and how you come to that beliefe. Implicite beleevers, ignorant beleevers, the adversary may swallow; but the understanding beleever, he must chaw, and pick bones, before he come to assimilate him, and make him like himself. (Potter and Simpson 4:7)
\end{abstract}

Notice that in this passage "implicit" faith does not simply mean faith by authority but any faith held without knowledge of its subject matter and knowledge of how it has come about. Donne's point belongs to Protestant normal science, but the point is precisely to see how a Catholic devotional manual and a Protestant sermon converge to reproduce something like the Pauline distinction between belief, on the one hand, and the kind of certain faith that is sustained by an act of thoughtful attentiveness.

Let me now return to Donne's poetry by suggesting that this is precisely the labour the Holy Sonnets as devotional poems are supposed to perform: the invention of faithas-proof, the going from imaginary and implicit faith to certain faith-as-proof. For reasons that are beyond the limit of this essay, in Donne's Holy Sonnets this means that the poems are primarily exercises of attention: in them, Donne uses poetry not to imagine the object of faith, but against itself, so to speak, to move away from imagination toward attention, toward attending to the object of faith and to attention as the foundation of certain faith. Donne regularly places doctrine at the end of the Holy Sonnets: the reason, I suggest, is that he uses the poem as the time and space in which the speaker can come to invent the faith-as-proof that allows him to proclaim the doctrine with certainty. These poems are not spontaneous prayers to God, 


\section{ATTENTION AS PROOF OF FAITH}

nor expressions of their author's faith; they are systematic exercises to establish certain faith for the speaker.

A brief example here is from another Holy Sonnet in which the move away from imagination, from images, toward attention, appears particularly clearly within the very first stanza:

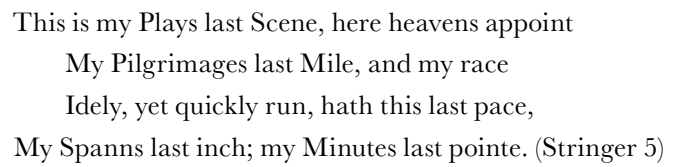

One influential reading of this poem is that in this stanza Donne aims to create what is called in the tradition of the Ignatian spiritual exercises a compositio loci; i.e. poetry is employed in the sonnet to systematically imagine a soteriologically significant place or situation - here, the moment of death.

At first this seems right: instead of naming "death" as its subject, the poem uses a series of images. But they come very quickly: play, pilgrimage, race replace each other; their transience suggests that they are replaceable, and what is left from them is only two smaller words: "my" and "last," the sort of skeleton of the poem's subject matter: the last of myself.

In fact, there is within the stanza a move away from the images, from imaging the moment of death, to something else: while at first the speaker imagines this "last of myself" in grand theatrical images of climax, by the end of the quatrain these give room to the mere "last inch" and the last instant of the speaker's personal "space and time." The poem moves toward trying to think the last moment without images, measured, so to speak, by the bare temporal and spatial extension of the self, by the extremities of this "me" who speaks.

This entropy works not only on the level of stripping the subject matter from images but also in the stanza's prosodic structure: the poem's movement in the first quatrain is literally self-consuming. From the beheaded rhymes ("appoint" and "point") to the enjambment that gradually shortens its overflow to disappear entirely by the last line, and to the caesuras that undergo an entropic process and find their most neutral, central position by the last line, all the formal poetic institutions participate in the performative movement whereby the poem internalises and produces its initial deixis. It is not just that by the end "my last" is figured by the speaker's body; it is figured by the poem's body; so that attention must look where the poem dictates 


\section{DÁVID MARNO}

it to look: the poetic images of the first two lines are left behind as mere distractions. Or rather, the poem strives to produce the lastness itself, as a minimal chronotopic unit, in order to force attention to attend to this minimal unit. It is as though the poem tried to create, out of its own material of words and images, a trap for attention, a locus where attention cannot look anywhere beyond the limits of this "my last."”

Let me now return to the poem that I quoted at the beginning of this essay to show how this logic of exercising attention works to produce a faith that is not in vain; how Donne relies on poetry to reproduce a version of Paul's argument. Allow me quote the poem in full here:

\footnotetext{
Death be not proud, thou some have called thee

Mighty and dreadful, for thou art not so.

For those whom thou thinkst thou dost overthrow

Dy not poore death, nor yet canst thou kill me.

From rest and sleepe, which but thy pictures be,

Much pleasure; then from thee much more must flow,

And soonest our best men with thee do go,

Rest of their bones, and Soules delivery.

Thou art slave to fate, Chance, kings, and desperate men,

And dost with poyson, war, and sickness dwell;

And Poppy or Charms can make us sleep as well,

And easier then thy stroke, why swellst thou then?

One short sleepe past, we live eternally

And Death shalbe no more: Death thou shalt dy.
}

One way of reading this poem is in terms of a contest between imagination and attention. The poetic address to Death in the first line is also a prosopopeia, a figure often called personification, the device of putting face on an abstraction, an absence, often a dead person. Insofar as in this poem Death itself is addressed, Donne's use of prosopopeia here is simultaneously paradigmatic and self-reflective. Now, it is standard to think about prosopopeia in terms of imagination: when the poet addresses someone who is absent, we think that this address is the product of imagination's labour. And it is true that the poem begins, like every Holy Sonnet, with images and in general with the work of imagination. But how would this work of imagination lead to faith in the resurrection?

7 Note that this is precisely how Francis of Sales defines the function of the compositio loci: "Now by means of this imaginary scene we confine our mind within the mystery upon which we intend to meditate, so that it may not wander hither and thither, just as we confine a bird in a cage, 


\section{ATTENTION AS PROOF OF FAITH}

Initially, the poem's strategy is rather direct: it begins by naming three seemingly random properties of Death - pride, might, and dreadfulness - and then proceeds to deny Death each of these qualities in the three quatrains, dedicating one quatrain to each. But while the poem proceeds with this literal imitation of Paul's mockery of death, a paradoxical movement emerges. Death, the speaker claims is not mighty enough to kill, but in fact it is poor death who cannot kill. But when the next few lines proceed to suggest that death is just like sleep except more, it seems that death's very might, its power to kill, has been implicitly restored even as the speaker wanted to deny death's dreadfulness. The same thing happens again in the next two lines: the speaker now turns to taunting death's pride by arguing that death is a servant, a mere slave to the really mighty, ultimately reducing it to the level of "poyson, war, and sickness" - but in in this process death has become base, its dreadfulness has certainly returned again. The thing that is named "death" in the poem seems to behave like a suitcase that is too full: every time the speaker is trying to press down one of death's attributes, the previously taunted attributes return. Each denial provokes death to return still more forcefully in the subsequent quatrain. In other words, while the poem is trying to pay attention to Death by focusing on its properties (its dreadfulness, for instance), another quality escapes the poem's attention and thus back into the next quatrain.

How should we account for this odd dynamic of attention and inattention? The answer lies in an Augustinian logic of incarnate attention, which means primarily that the more attention we pay to something, the more distraction our attention generates at the same time; i.e. that distraction is the inevitable by-product of attending itself. Insofar as the fall created the kind of mortal, uncontrollable body that we live in, this continual distraction is in fact a synonym for mortality itself: the "scattering," the distention that Augustine identifies with life in the Confessions is life insofar as it is on the way towards death. Donne's poem performs this Augustinian logic with remarkable precision. Throughout the poem, death does not just escape the poem's attention, but it is in fact massively produced by the poem's attention, as the poem's own inattention. This explains why, at first sight at least, by the end the poem seems to produce, not a proof for the resurrection of the body but instead something that seems more like the resurrection of Death: "One short sleepe past, we live eternally / And Death shalbe no more: Death thou shalt dy." Notice that it is here, in the last line, that for the first time the poem turns away from its 


\section{DÁVID MARNO}

initial addressee, a personalised death; and it speaks about death in the third person ("Death shalbe no more"), as if the poem's taunting of death had by now definitely proved that death is going to die. But just as earlier when the denials of death's accidents resulted in the other accidents creeping back into the poem's body, now the ostensible final annihilation of death leads to the complete resurrection of death: as if waking from its own dream, the poem now returns from the apostrophe to face a fully present, personalised and capitalided death, the Death that the poem produced for itself, as its own, personal inattention and Death. ${ }^{8}$

But the poem's victory lies precisely in this final face-off between the resurrected Death and the poem's attention. If throughout the poem death was invoked but always slipped out of attention, it is here in the last line that Death fully returns, as the paradoxical invention of the poem itself, made out of its own body, of its own dialectic of attention and inattention, and yet somehow despite its own intention. It is here that the poem finally succeeds in making Death, that is, its own inattention, the subject of its attention; this act of attending to death as the poem's own inattention that Donne performs a poetic version of Paul's faith-as-proof. In other words: this poem does not simply imagine that death is overcome; instead it attends to Death's death and thereby establishes the possibility of certain faith in the resurrection of the dead.

\section{III}

Let me conclude here by making a brief comment on some of the consequences of this reading that extend beyond Donne's poem, or indeed beyond poetry and devotion. By the second half of the seventeenth century, the concept of attention becomes ubiquitous in philosophy and in the sciences: from Malebranche to Robert Boyle, thinkers rely on it in making methodological and epistemological remarks about their systems. This trend is particularly striking in the writings of Descartes, who, having defined truth as "whatever I perceive very clearly and distinctly," goes on to say, "I term clear that which is present and open to an attentive mind" (Philosophical Writings 76). ${ }^{9}$ It would be easy to miss this and other, similarly brief

8 Helen Gardner observes that all the MSs "agree in giving the second 'death' a capital" (70).

9 The Principia states: "I call that perception which is present and manifest to an attentive mind [Claram voco illam, quae menti attendenti praesens et aperta est]" (Descartes, Principles 20). 


\title{
ATTENTION AS PROOF OF FAITH
}

references to attention, were it not for the fact that they return in Descartes's response to one of the objections to the Meditations, this time in a more fully articulated form:

\begin{abstract}
So long as we attend to a truth which we perceive very clearly, we cannot doubt it. But when, as often happens, we are not attending to any truth in this way, then even though we remember that we have previously perceived many things clearly, nevertheless there will be nothing which we may not justly doubt so long as we do not know that whatever we clearly perceive is true. (The Philosophical Writings of Descartes 2:309)
\end{abstract}

Descartes's remarkable and often ignored claim in this passage is that truth is certain as long as we attend to it, whereas the slightest inattention will introduce doubt. In the praxis of Cartesian philosophy, the mere perception of something that clearly and distinctly appears to be true is not in itself sufficient to provide a foundational principle for the entire system; what is also required is the act of attention. Like in Donne's sonnets, attention is key for reaching and sustaining certainty - it is just that for Descartes this certainty is no longer an attribute of faith.

\section{Works Gited}

Brou, Alexandre, S. J. Ignatian Methods of Prayer. Trans. William S. Young, S.J. Milwaukee: The Bruce Publishing Company, 1949.

Descartes, René. Philosophical Writings, trans. Elizabeth Anscombe and Peter Thomas Geach (Edinburgh: Nelson, 1962)

- Principles of Philosophy. Trans. Valentine Rodger Miller and Reese P. Miller. Dordrecht: Kluwer, 1991.

- The Philosophical Writings of Descartes. Trans. J. Cottingham, R. Stoothoff, D. Murdoch, and A. Kenny. Cambridge: Cambridge University Press, 1984.

Gardner, Helen, ed. Fohn Donne: The Divine Poems. Oxford: Oxford University Press, 1952.

Granada, Luis de. Meditations. London, 1633.

Potter, George, and Evelyn M. Simpson, eds. The Sermons of John Donne. 10 vols. Berkeley: University of California Press, 1953-1962.

Stringer, Gary A., ed. The Variorum Edition of the Poetry of John Donne, volume 7, part I, The Holy Sonnets. Bloomington: Indiana University Press, 2005. 


\section{DÁVID MARNO}

\section{Contributor Details}

Dávid Marno is associate professor of English at the University of California, Berkeley, where he teaches Renaissance poetry and drama. He is author of Death Be Not Proud: The Art of Holy Attention (Chicago, 2016), a book focusing on John Donne's poetry and religious techniques of attentiveness. He is currently working on two projects: a volume on prayer and its literary afterlives, and a study of the English Department as a cultural phenomenon. 